\title{
Respiratory muscle strength no influence the need for noninvasive ventilation after heart surgery
}

\author{
Força muscular respiratória não influencia no uso da ventilação não invasiva \\ após cirurgia cardiaca
}

\author{
La fuerza muscular respiratoria no influye en el uso de la ventilación no invasiva \\ tras cirugía cardiaca
}

Christiane Riedi Daniel', Taissa Driessen², Andersom Ricardo Fréz', Cintia Teixeira Rossato Mora²

\begin{abstract}
I The aim of this study was to investigate the relation between preoperative respiratory muscle strength and indication and performance of noninvasive ventilation in the planned heart surgery. We conducted a retrospective study using data collected from clinical records and analyzed 109 medical records and noninvasive ventilation accompanying paper. We analyzed the values of respiratory muscle strength, peak flow and respirometry, as well as the postoperative respiratory complications, correlating them with indication and performance of the noninvasive ventilation. The $t$ test was performed for continuous variables; the chi-square was used to investigate the influence of preoperative respiratory muscle strength values in the indication of noninvasive ventilation. Noninvasive ventilation was used in 32 (29\%) subjects and the prime motive indication was hipercapy (44\%). The successful use of noninvasive ventilation was observed in $94 \%$. The decrease in preoperative strength, despite having a lower performance, showed no significant difference in relation to its use and outcome ( $p=0.73$ ). The preoperative respiratory muscle strength was not able to provide for the use of noninvasive ventilation or its performance.
\end{abstract}

Keywords I Thoracic Surgery; Noninvasive Ventilation; Muscle Strength.

RESUMO I O objetivo deste estudo foi verificar a relação entre a força muscular respiratória pré-operatória e a indicação e o desempenho da ventilação não invasiva em pacientes submetidos à cirurgia cardíaca eletiva. Foi realizado um estudo retrospectivo por levantamento e análise de 109 prontuários e fichas de acompanhamento da ventilação não invasiva. Foram analisados força muscular respiratória, pico de fluxo e ventilometria e complicações pós-operatórias, correlacionando-as com a indicação e o desempenho da ventilação não invasiva. Foi utilizado o teste $t$ de Student para as variáveis contínuas e teste quiquadrado para investigar a influência dos valores da força muscular respiratória pré-operatória com a indicação de desfecho da ventilação não invasiva. A ventilação não invasiva foi utilizada em 32 (29\%) dos indivíduos, sendo a principal indicação a hipercapnia (44\%). O sucesso com o uso da ventilação não invasiva foi de $94 \%$. A diminuição da força muscular pré-operatória, apesar de ter apresentando um menor desempenho, não demostrou diferença significativa em relação à sua utilização e desfecho $(p=0,73)$. A força muscular respiratória pré-operatória não foi capaz de prever a utilização da ventilação não invasiva nem seu desempenho.

Descritores I Cirurgia Torácica; Ventilação Não Invasiva; Força Muscular.

RESUMEN I El objetivo de este estudio fue verificar la relación entre la fuerza muscular respiratoria preoperatoria y la indicación y el desempeño de la ventilación no invasiva en pacientes sometidos a cirugía cardíaca electiva. Se llevó a cabo un estudio retrospectivo por encuesta y análisis de 109 registros hospitalarios y formularios de acompañamiento de la ventilación no invasiva. Se analizaron la fuerza muscular respiratoria, el pico de

Study conducted at the Hospital Ministro Costa Cavalcanti - Foz do Iguaçu (PR), Brazil.

1Physical Therapy Department of the Universidade Estadual do Centro-Oeste (UNICENTRO) - Guarapuava (PR), Brazil.

${ }^{2}$ Hospital Ministro Costa Cavalcanti - Foz do Iguaçu (PR), Brazil. 
flujo y ventilometría, y complicaciones postoperatorias, correlacionándolas con la indicación y el desempeño de la ventilación no invasiva. Se utilizó el test t de Student para las variables continuas y el test chi-cuadrado para investigar la influencia de los valores de la fuerza muscular respiratoria preoperatoria con la indicación de resultado de la ventilación no invasiva. La ventilación no invasiva fue utilizada en 32 (29\%) de los individuos, siendo la principal indicación la hipercapnia (44\%). El éxito en la utilización de la ventilación no invasiva fue de 94\%. La disminución de la fuerza muscular preoperatoria, aunque haya presentado un menor desempeño, no demostró diferencia significativa en cuanto a su utilización y resultado ( $p=0,73$ ). La fuerza muscular respiratoria preoperatoria no fue capaz de prever el uso de ventilación no invasiva o su desempeño.

Palabras clave | Cirugía Torácica; Ventilación no Invasiva; Fuerza Muscular.

\section{INTRODUCTION}

The prior condition of the patient undergone cardiac surgery - such as the presence of chronic lung disease, which may be associated with other co-morbities and living habits - contributes to the intensity of the respiratory alterations in the postoperative period (PO), being the atelectasis, the infections and the respiratory failure, the most common alterations found ${ }^{1-3}$.

In addition to these preoperative conditions, there are also some perioperative factors which have a direct impact on the increased risk of morbidity and mortality and in the time length and costs of hospitalizations ${ }^{1,3-5}$. Among the factors related to the procedure are surgical trauma, pain, anesthesia and extracorporeal circulation (ECC), resulting in diaphragmatic dysfunction, decrease of pulmonary function and expansion, hypoxia and accumulation of secretions ${ }^{5}$.

Thus, the preoperative evaluation becomes important, aiming to identify possible risks for respiratory complications. In this evaluation, one shall analyze the respiratory muscle strength, since the weakness of these muscles in preoperative stage is related to pulmonary complications in $\mathrm{PO}^{1}$.

One of the ways to reduce these complications is the intervention of preoperative physical therapy, which includes inspiratory muscle training. Patients who receive this intervention present shorter hospitalization time in the myocardial revascularization $\mathrm{PO}^{6,7}$. Besides the preoperative stage, physical therapy aims at preventing and treating PO complications. Within therapeutic alternatives, the noninvasive ventilation (NIV) has been used in order to improve respiratory function as a result of the deterioration of the cardiac function ${ }^{8,9}$.

The NIV is indicated in the prevention and solution of respiratory failure, reducing the PO's reintubation rates, pneumonia and hypoxemia, impacting directly on hospitalization time length and at the intensive care unit (ICU) ${ }^{3,10-12}$. The NIV also improves gas exchange and shunt, decreasing muscle work, pre- and afterload, reflecting in ventricular performance ${ }^{3,11}$.
The aim of this study was to investigate the relation between preoperative respiratory muscle strength and the recommendation and performance of NIV in elective cardiac surgery. Secondarily, it aimed at comparing the types of surgical interventions, the characteristics of the procedures (time of extracorporeal circulation, anesthesia, surgery, hospitalization and hospital discharge) as well as the characteristics of the individuals provided with respiratory muscle strength.

\section{METHODOLOGY}

A retrospective, observational study developed through the survey and analysis of hospital records and NIV monitoring charts from individuals who have undergone cardiac surgery from January to December 2011. The study was approved by the Ethics Committee of the Assis Gurgaz College, protocol 221/2007.

\section{Sample}

193 medical charts of patients who have undergone myocardial revascularization, who had their valves replaced, and who had their aneurysms and atrial septal defect corrected, were found, between January and December 2011. Of these, 84 were excluded for being emergency surgeries, for being patients with unstable angina, who were not in proper physical nor cognitive condition for the fulfillment of the breathing tests, or who died postoperatively. Thus, 109 charts were analyzed; as they were standard charts, all records possessed the necessary information.

\section{Preoperative evaluation}

All subjects were evaluated at hospital admission, when their medical records were registered, along with their respiratory strength, flow peak and ventilometry. 
The respiratory tests were performed with the patients sitting down, with their feet being supported and their nostrils occluded with a nose clip.

The respiratory muscle strength was measured using the analog manovacuometer (Wika, $300 \mathrm{MV}$ ), with a range of $\pm 300 \mathrm{cmH}_{2} \mathrm{O}$. The maximum inspiratory pressure (MIP or PImax) was measured starting with three respiratory cycles in tidal volume (VT), and an expiration, to residual volume (RV), was requested. In the sequence, the patient performed a maximum inspiration to total lung capacity (TLC), sustaining the intake force for two seconds ${ }^{13}$. In order to evaluate the expiratory pressure (MEP or PEmax), the patient was oriented to perform intakes in VT followed by a deep intake until TLC and then perform a maximum expiration at VT level, sustaining it for two seconds ${ }^{13}$. Both maneuvers were performed three times, in intervals determined by the patients, the best measures being recorded then. In order to calculate the projected pressure, the equations proposed by Neder et al. ${ }^{14}$ were used. For the comparison of the preoperative respiratory muscle strength with the use of NIV, and its outcomes, it was considered MIP of $80 \mathrm{cmH}_{2} \mathrm{O}$. According to the guidelines of the American Thoracic Society/European Respiratory Society (ATS/ERS) ${ }^{15}$, in pulmonary function tests, values below this one may indicate muscle weakness.

In order to check the peak of the flow, the patient was oriented to perform an intake up to the TLC, followed by a forced, short and explosive maximum expiration in a peak flow gauge device. The highest value out of the three consecutive maneuvers was registered, and in case the difference between them was higher than $20 \mathrm{~L} / \mathrm{min}$, the test would be repeated.

For the conducting of the respirometry (Inspire Wright Mk 8) a heat exchanger filter was used as an intermediate, which was attached to the patient's mouth. For the measurement of the minute volume (Vmin), the volunteer would perform a calm ventilation for one minute and, at the end, the value found and the number of breaths in the period would be registered. For the measuring of the VT, the Vmin was divided by the respiratory rate $(\mathrm{RR})$ found. The measurement of the vital capacity (VC) was evaluated by an expiration to the RV followed by an inspiration to the TLC.

\section{Physiotherapeutic intervention}

After surgery, the physiotherapeutic interventions were conducted three times a Day, with respiratory and motor exercises, from the immediate $\mathrm{PO}$ to the medical discharge. It was the responsibility of the physical therapist to manage mechanical ventilation, extubation, evaluation and recommendation of NIV, in consensus with the multidisciplinary team.

\section{Noninvasive ventilation}

The recommendation of the NIV was based on the hospital's protocol, which included: presence of acute respiratory failure (ARF), characterized by the presence of respiratory effort; tachypnea; need for fractions of inspired oxygen $\left(\mathrm{FiO}_{2}\right)$ higher than $40 \%$ with peripheral oxygen saturation $\left(\mathrm{SpO}_{2}\right)$ lower than $90 \%$; acute pulmonary edema (APE) defined by the presence of respiratory effort associated to cough with pinkish sputum and the presence of pulmonary noise on auscultation; hypoxemia (alterations in $\mathrm{PO}_{2}$ without manifestation of respiratory effort) or hypercapnia alone; bronchospasm (respiratory effort associated to expiratory wheezing on auscultation); radiological alterations (atelectasis and pleural effusion); or prophylactic post-extubation (patients with respiratory disease, in mechanical ventilation for longer than 24 hours).

Patients would be continuously reassessed, taking as parameter the signs of respiratory effort, and $\mathrm{SpO}_{2}$ level of consciousness. After two hours of NIV initiation, a new analysis of the arterial gasometry was performed. The patients who presented good response to the NIV (improvement of oxygenation and/or hypercapnia) would remain in treatment, performed three times a day, for a period of two hours, until the favorable closure of the clinical condition.

Were considered as indicative of failure in the use of NIV: need for a $\mathrm{FiO}_{2}$ higher than 0.6, decrease in $\mathrm{pH}$ and/or increase of the $\mathrm{PaCO}_{2}$, respiratory frequency higher than 35ipm, agitation or decreasing of consciousness level, hemodynamic instability, arrhythmias, myocardial ischemia, abdominal distention, intolerance to the mask and respiratory worsening.

For the classification of postoperative pulmonary complications of cardiac surgery, the proposal of Hulzebos et al. ${ }^{16}$ was used, subdividing them into four classification categories:

- Type 1: dry cough, microatelectasis and temperature higher than $37.5^{\circ} \mathrm{C}$ without documented cause, dyspnea without documented cause;

- Type 2: productive cough not associated to the right cause, bronchospasm (wheezing) and the need for change in the treatment, hypoxemia with wheezing 
and dyspnea signs and symptoms, atelectasis with radiological confirmation associated to temperature higher than $37.4^{\circ} \mathrm{C}$ or abnormal lung findings, hypercapnia in need of treatment;

- Type 3: pleural effusion requiring thoracentesis, suspected pneumonia (radiologic evidence without bacterial confirmation), pneumonia with both radiologic and bacterial confirmation), pneumothorax, reintubation (with mechanical ventilation period of no more than $48 \mathrm{~h}$ ).

- Type 4: ventilation failure: postoperative ventilator dependency exceeding 48h, intubation with subsequent dependence on mechanical ventilation for more than $48 \mathrm{~h}$.

Table 1. Sample characterizationCaracterização da amostra

\begin{tabular}{|c|c|c|c|}
\hline & $\begin{array}{c}\text { PImáx<80 } \mathrm{cmH}_{2} \mathrm{O} \\
\mathrm{n}=70 \\
\mathrm{n}(\%)\end{array}$ & $\begin{array}{c}\text { PImáx }>80 \mathrm{cmH}_{2} \mathrm{O} \\
\mathrm{n}=39 \\
\mathrm{n}(\%)\end{array}$ & $\mathrm{p}$-value \\
\hline Average age (years)\# & $59.2 \pm 12.1$ & $57.3 \pm 12.9$ & 0.45 \\
\hline \multicolumn{4}{|l|}{ Gender } \\
\hline Male & $47(67)$ & $19(49)$ & \multirow{2}{*}{0.09} \\
\hline Female & $23(33)$ & $20(51)$ & \\
\hline $\mathrm{BMI}\left(\mathrm{kg} / \mathrm{m}^{2}\right)$ & $28.3(5.6)$ & $28.2(4.2)$ & 0.87 \\
\hline $\begin{array}{l}\text { Abdominal } \\
\text { circunference (cm) }\end{array}$ & $99.2(12.5)$ & $98.1(11.6)$ & 0.65 \\
\hline \multicolumn{4}{|l|}{ Smoking habit } \\
\hline Non smoker & $35(50.0)$ & $20(51.2)$ & \multirow{3}{*}{0.55} \\
\hline Smoker & $5(7.2)$ & $5(12.8)$ & \\
\hline Former smoker & $30(42.8)$ & $14(36.0)$ & \\
\hline Diabetes & $27(38.5)$ & $13(33.3)$ & 0.73 \\
\hline Dyslipidemia & $32(46)$ & $15(38.5)$ & 0.59 \\
\hline Hypertension & $54(77)$ & $27(69)$ & 0.49 \\
\hline Respiratory diseases & $5(7.1)$ & $7(17.9)$ & 0.16 \\
\hline
\end{tabular}

MIP: maximum inspiratory pressure; BMI: Body mass index; "Mean \pm standard deviation

\section{Statistical analysis}

In order to differentiate the groups according to muscle strength, the Student's t-test for the continuous variables was used, while the $\chi^{2}$ test was used for the categorical ones. The $\chi^{2}$ test was also used to investigate the influence of the values of preoperative respiratory muscle strength with the recommendation for NIV. The choice of MIP > or $<80 \mathrm{~cm} \mathrm{H}_{2} \mathrm{O}$ for the comparison of the muscular strength with the use of NIV was given because this value was determined by the ATS/ERS ${ }^{15}$ within the guidelines for pulmonary function testing, with values indicating muscle weakness. The rest of the data were presented in tables with the distribution of the frequency, the average and the standard deviation. The level of significance was set at 5\%. The analysis were performed using the GraphPad Instat 3.0 software.

\section{RESULTS}

109 charts, of patients who had undergone cardiac surgery, were consulted, from which the patients' characteristics (Table 1) and the performed surgical procedures' characteristics were extracted (Table 2).

The NIV was used in 32 (29\%) patients, from which 30 (94\%) were successful and 2 (6\%) were unsuccessful, both being re-intubated because of worsening in the respiratory condition (Table 3).

From the 109 investigated patients, 35 (32\%) have presented postoperative respiratory complications, and

Table 2. Characteristics of the performed surgical procedures

\begin{tabular}{|c|c|c|c|}
\hline & $\begin{array}{c}\mathrm{MIP}<80 \mathrm{cmH}_{2} \mathrm{O} \\
\mathrm{n}=70 \\
\mathrm{n}(\%)\end{array}$ & $\begin{array}{c}\mathrm{MIP}>80 \mathrm{cmH}_{2} \mathrm{O} \\
\mathrm{n}=39 \\
\mathrm{n}(\%)\end{array}$ & $\mathrm{p}$-value \\
\hline \multicolumn{4}{|l|}{ Kind of surgery } \\
\hline Myocardial revascularization & $43(61)$ & $23(60)$ & \multirow{5}{*}{0.17} \\
\hline Replacement of the mitral valve & $4(6)$ & $8(20)$ & \\
\hline Replacement of the aortic valve & $11(16)$ & $4(10)$ & \\
\hline Associated surgeries & $9(13)$ & $3(8)$ & \\
\hline Other surgeries & $3(4)$ & $1(2)$ & \\
\hline \multicolumn{4}{|l|}{ Surgical risk } \\
\hline ASA I & $3(4)$ & 2(6) & \multirow{4}{*}{0.97} \\
\hline ASA ॥ & $9(13)$ & $6(15)$ & \\
\hline ASA III & $5(73)$ & 27(69) & \\
\hline ASA IV & $7(10)$ & $4(10)$ & \\
\hline Time of extracorporeal circulation (min) & $88.1 \pm 49.9$ & $88.1 \pm 48.4$ & 0.99 \\
\hline Anesthesia time $(\mathrm{min})^{\sharp}$ & $300.7 \pm 97.7$ & $295.8 \pm 81.5$ & 0.79 \\
\hline Surgery time $(\mathrm{min})^{\sharp}$ & $267.7 \pm 71.7$ & $254.0 \pm 69.0$ & 0.34 \\
\hline Hospitalization time (days) $)^{\#}$ & $10.8 \pm 6.1$ & $9.8 \pm 5.7$ & 0.22 \\
\hline Time of PO in hospital discharges (days) & $7.5 \pm 5.5$ & $6.0 \pm 3.6$ & 0.12 \\
\hline
\end{tabular}


from those, 19 (54\%) made use of the NIV. It is noteworthy that not all patients who used NIV had postoperative pulmonary complications, according to the classification of Hulzebos et al. ${ }^{16}$.

The average maximal inspiratory and expiratory pressures assessed preoperatively were $62.8 \pm 25.7$ and $68.6 \pm 22.5 \mathrm{cmH}_{2} \mathrm{O}$, respectively. Meanwhile, the peak of expiratory flow found was $346.7 \pm 125.8 \mathrm{~L} / \mathrm{min}$.

The findings in respirometry were: minute volume average of $11,375.0 \pm 10,546.4 \mathrm{~mL}$, tidal volume of $749.3 \pm 396.3 \mathrm{~mL}$ and inspiratory capacity of 2,761.4 $\pm 1,328.2 \mathrm{~mL}$, with no significant difference between patients who used NIV $(p=0.47)$ and the results of it $(\mathrm{p}=0.09)$.

Significant differences were not found when comparing the muscle strength, the use of NIV and its results (Table 4).

\section{DISCUSSION}

The rate of respiratory complications in the postoperative period of cardiac surgery is between 7 and $49 \%^{3,17}$. These complications are one of the main causes of morbidity and mortality in patients who have undergone myocardial revascularization surgery ${ }^{18}$. In this study, $60 \%$ of the individuals have been revascularized, and from those, $32 \%$ presented respiratory complications. These results are similar to another study's ${ }^{3}$, which reported a $30 \%$ rate of postoperative complications.

The NIV is used as a tool for reversing of these PO complications, which may reduce the need for re-intubation, rates of mobidity, mortality and ICU hospitalization time lenght ${ }^{19}$. Its use is recommended by the International Consensus Conferences in Intensive Care Medicine ${ }^{11}$.

In a literature review ${ }^{7}$, it was found that the use of NIV in PO patients has a level II degree of recommendation. Fact that differs from another study ${ }^{6}$, and also from this one, in which was observed a $94 \%$ success rate.

There was a total of $29 \%$ of patients who had undergone cardiac surgery and made use of NIV. This frequency is similar to another study's ${ }^{20}$, in which the use of NIV was investigated in patients with PO respiratory insufficiency after cardiac surgery, and the authors have observed that $33 \%$ of them needed this ventilator support. However, in the Hospital Ministro Costa Cavalcanti's protocol, the recommendation was not only for the cases of respiratory insufficiency, as referred in the study.
Table 3. Indications and outcomes of noninvasive ventilation

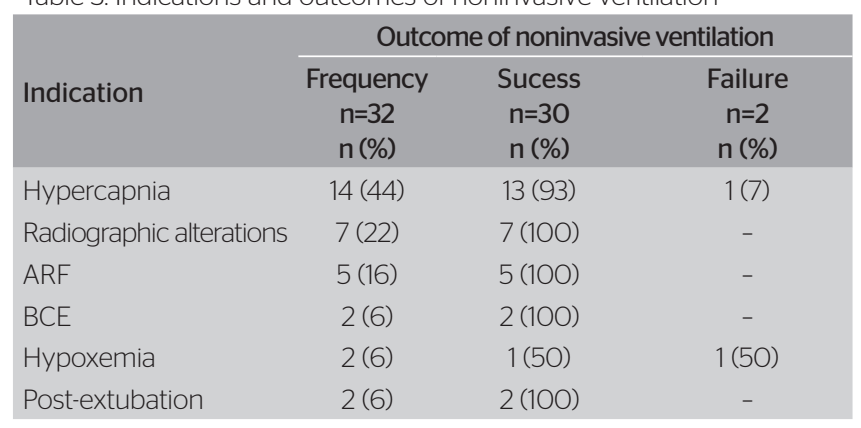

ARF: Acute pulmonary respiratory failure; BCE: bronchospasm; NIV: Noninvasive ventilation

Table 4. Relationship between respiratory muscle strength, use and outcome of noninvasive ventilation

\begin{tabular}{lcccccc} 
& \multicolumn{3}{c}{$\begin{array}{c}\text { Use of NIVI } \\
\mathrm{n}=109\end{array}$} & \multicolumn{3}{c}{$\begin{array}{c}\text { Results of NIV } \\
\mathrm{n}=33\end{array}$} \\
\cline { 2 - 8 } & $\begin{array}{c}\text { Yes } \\
\mathrm{n}(\%)\end{array}$ & $\begin{array}{c}\text { No } \\
\mathrm{n}(\%)\end{array}$ & p-value & $\begin{array}{c}\text { Sucess } \\
\mathrm{n}(\%)\end{array}$ & $\begin{array}{c}\text { Failure } \\
\mathrm{n}(\%)\end{array}$ & p-value \\
$>80 \mathrm{cmH}_{2} \mathrm{O}$ & $14(13)$ & $26(24)$ & & $13(40)$ & $1(3)$ & 0,73 \\
$<80 \mathrm{cmH}_{2} \mathrm{O}$ & $19(17)$ & $50(46)$ & 0,54 & $17(51)$ & $2(6)$ &
\end{tabular}

NIV: noninvasive ventilation; MIP: maximum inspiratory pressure

The highest use frequency of NIV was observed in patients with hypercapnia (44\%), whose success was $93 \%$. The use of NIV for this purpose is widely spread. A study ${ }^{12}$ has invetigated the factors associated to the response factors of NIV on the fisrt day of ICU hospitalization, in hypercapnic patients, despite the success being lower than in the present study (66\%), it was possible to identify that patients who needed higher support pressures were the ones who presented higher chances of failures or unsuccess ${ }^{12}$.

Lee et $a l^{21}$ demonstrated that patients with $\mathrm{PO}$ complications can be treated with NIV, reducing both hospitalization and ICU time length, the most common complications being pneumonia and atelectasis. Olper et al. ${ }^{22}$ achieved $85 \%$ success in the use of NIV PO cardiac surgery, where the causes of respiratory insufficiency were mainly atelectasis and pleural effusion. Although the main indication of this study being hypercapnia (44\%), the performance of NIV was similar, with $94 \%{ }^{14,22}$.

Bellinetti e Thomson ${ }^{23}$ describe that patients with MIP and MEP 75\% below what was predicted develop more respiratory complications ${ }^{12}$. These groups having greater incidence of respiratory complications also require greater use of NIV, which occured in this study, with no significant difference however. Schnaider et al. ${ }^{1}$ and Bastos et al. ${ }^{24}$ did not find any significant difference in pulmonary complications in patients with preoperative reduced respiratory muscle strength, however, in both studies the complications were more frequent 
in these patients ${ }^{15}$. The data found in this study were similar, because the use of NIV was higher in patients with MIP $<80 \mathrm{cmH}_{2} \mathrm{O}$, but without significant difference. Hulzebos et al. ${ }^{16}$ demonstrated that patients who received inspiratory muscle training before surgery had $30 \%$ fewer respiratory complications. In the present study, the use of NIV showed no significant difference in patients with MIP $<80 \mathrm{cmH}_{2} \mathrm{O}$, but all unsuccessful cases were patients with $\mathrm{MIP}<80 \mathrm{cmH}_{2} \mathrm{O}$.

The use of NIV prophylactically, i.e. with no signs or symptoms of respiratory insufficiency, has been used in order to prevent respiratory complications. A literature review ${ }^{25}$ has highlighted that NIV, associated with respiratory physical therapy, is a safe and effective resource to reduce and treat PO complications. In this study, $22 \%$ of NIV occured in patients who had been radiologicaly involved, however, without clinical manifestations, and 6\% immediately after extubation, due to preoperative risk factors. Thus, $28 \%$ have used it in a preventive way. A randomized study ${ }^{26}$ used NIV in a prophylactic way in 500 patients, and demonstrated that NIV improves oxygenation, reduces respiratory complications and hospital readmissions. The preventive use of NIV within 48 hours after cardiac surgery, improves the values of ventilometry, respiratory muscle strength and peak of expiratory flow, which can prevent respiratory complications $s^{5,25,26}$.

The subjects studied were characterized overweight (average BMI $28 \mathrm{~kg} / \mathrm{m}^{2}$ ). According to the BMI classification, 33\% presented with some degree of obesity, and of these, $36 \%$ made use of NIV. The use of NIV in obese patients with hypercapnia is effective, however, there is a need for a higher level of PEEP, resulting in improved oxygenation, and decreased carbon dioxide and alveolocapillar difference ${ }^{12}$. Another anthropometric factor evaluated was the waist circumference, which had an average of $98 \mathrm{~cm}$, being more prone to common respiratory complications in obese patients.

As a consequence of cardiac surgery, individuals have lung alterations that favor the development of postoperative pulmonary complications ${ }^{22}$. From these complications and from respiratory muscle strength, it is known that their weakness increases the respiratory work load, which may result in different clinical consequences, such as dyspnea and the need of use of accessory muscles of respiration ${ }^{27}$. It is believed that preoperative factors can minimize or worsen this condition, and these have been widely investigated, mainly the influence of these factors on postoperative complications ${ }^{22}$.
The studies of Riedi et al. ${ }^{28}$ and Bastos et al. ${ }^{24}$ showed a decrease in postoperative respiratory muscle strength, when compared to the pre values, however, it was found no relation between preoperative dysfunction of respiratory muscles with postoperative pulmonary complications, and these are similar results to those found in this study.

In contrast to all, the study of Savci et al..$^{29}$ found that preoperative respiratory muscle training, with the goal of improving muscle strength, decreased the length of hospitalization in the ICU and led to the recovery of respiratory muscle more quickly. In another study, Hulzebos et al. ${ }^{16}$ investigated preoperative factors that could influence the appearence of postoperative pulmonary complications, and found no relation to respiratory muscle weakness, however, it was verified that the maintenance of MEP 75\% above what was predicted, was a protective factor.

Based on this, it is believed that perhaps the weakness of the respiratory muscles is not directly related to postoperative pulmonary complications, however, adequate respiratory muscle strength may contribute to a better and faster reestablishment of respiratory functions, lost due to the surgical procedure.

This study was limited to a sample of people who had undergone cardiac surgery at a hospital in Foz do Iguaçu, Paraná. It is suggested for the study to be continued, however longitudinally, including follow-up studies, seeking to better identify the factors which affect quality of life and the functional status of these patients.

\section{CONCLUSION}

The use of NIV was effective and safe for patients in the PO of cardiac surgery. However, no relation between preoperative decreased respiratory muscle strength and the recommendation and result of NIV was found.

\section{REFERENCES}

1. Schnaider J, Karsten M, Carvalho T, Lima WC. Influência da força muscular respiratória pré-operatória na evolução clínica após cirurgia de revascularização do miocárdio. Fisioter Pesq. 2010;17(1):52-7.

2. Laizo A, Delgado FEF, Rocha GM. Complicações que aumentam o tempo de permanência na unidade de terapia intensiva na cirurgia cardíaca. Rev Bras Cir Cardiovasc. 2010;25(2):166-71. 
3. Liao G, Chen R, He J. Prophylactic use of noninvasive positive pressure ventilation in postthoracic surgery patients: A prospective randomized control study. J Thorac Dis. 2010;2(4):205-9.

4. Dias CM, Vieira RO, Oliveira JF, Lopes AJ, Menezes SLS, Guimarães FS. Três protocolos fisioterapêuticos: efeitos sobre os volumes pulmonares após cirurgia cardíaca. J Bras Pneumol. 2011;37(1):54-60.

5. Franco AM, Torres FCC, Simon ISL, Morales D, Rodrigues AJ. Avaliação da ventilação não invasiva com dois níveis de pressão positiva nas vias aéreas após cirurgia cardíaca. Rev Bras Cir Cardiovas. 2011;26(4):582-90.

6. Miranda RCV, Padulla SAT, Bortolatto CR. Fisioterapia respiratória e sua aplicabilidade no período pré-operatório de cirurgia cardíaca. Rev Bras Cir Cardiovas. 2011;26(4):647-52.

7. Romero JMG, García TG, Chust JNS, Martínez MG. Ventilación no invasiva. Arch Bronconeumol. 2010;46(Suppl. 6):14-21.

8. Westerdahl E, Möller M. Physiotherapy-supervised mobilization and exercise following cardiac surgery: a national questionnaire survey in Sweden. J Cardiothorac Surg. 2010;5:67.

9. Guarracino F, Ambrosino N. Non invasive ventilation in cardio-surgical patients. Minerva Anestesiol. 2011;77(7):734-41.

10. Chiumello D, Chevallard G, Gregoretti C. Non-invasive ventilation in postoperative patients: a systematic review. Intensive Care Med. 2011;37(6):918-29.

11. American Thoracic Society, European Respiratory Society, Eruopean Society of Intensive Care Medicine, Société de Réanimation de Langue Française. International Consensus Conferences in Intensive Care Medicine: noninvasive positive pressures ventilation in acute respiratory failure. Am J Respir Crit Car Med. 2001;16(3):283-91.

12. Gursel, G, Aydogdu M, Gulbas G, Ozkaya S, Tasyurek S, Yildirim F. The influence of severe obesity on non-invasive ventilation (NIV) strategies and responses in patients with acute hypercapnic respiratory failure attacks in the ICU. Minerva Anestesiol. 2011;77(1):17-25.

13. Souza RB. Pressões respiratórias estáticas máximas. J Pneumol. 2002;28(Suppl. 3):S155-65.

14. Neder JA, Andreoni S, Lerario MC, Nery LE. Reference e values for lung function tests. II. Maximal respiratory pressures and voluntary ventilation. Braz J Med Biol Res. 1999;32(6):719-27.

15. American Thoracic Society/European Respiratory Society. ATS/ERS Stantement on respiratory muscle testing. Am J Respir Crit Care Med. 2002:166(4):518-624.

16. Hulzebos EH, Van Meeteren NL, De Bie RA, Dagnelie PC, Helders PJ. Prediction of postoperative pulmonary complications on the basis of preoperative risks factors in patients who had undergone coronary bypass graft surgery. Phys Ther. 2003;83(1):8-16.

17. Ortiz LDN, Schaan CW, Leguisamo CP, Tremarin K, Mattos WLL, Kalil RK, et al. Incidência de complicações pulmonares na cirurgia de revascularização do miocárdio. Arq Bras Cardiol. 2010;95(4):441-7.
18. Moreno AM, Castro RR, Soares PP, Sant'Anna M, Cravo SL, Nóbrega AC. Longitudinal evaluation the pulmonary function of the pre and postoperative periods in the coronary artery bypass graft surgery of patients treated with a physiotherapy protocol. J Cardiothorac Surg. 2011;6:62.

19. Zoremba M, Kalmus G, Begemann D, Eberhart L, Zoremba N, Wulf $\mathrm{H}$, et al. Short term non-invasive ventilation post-surgery improves arterial blood-gases in obese subjects compared to supplemental oxygen delivery - a randomized controlled trial. BMC Anesthesiology. 2011;1:10.

20. Kilger E, Möhnle P, Nassau K, Beiras-Fernandez A, Lamm P, Frey L, et al. Noninvasive mechanical ventilation in patients with acute respiratory failure after cardiac surgery. Heart Surg Forum. 2010;13(2):E91-5.

21. Lee BC, Kyoung KH, Kim YH, Hong SK. Non-invasive ventilation for surgical patients with acute respiratory failure. J Korean Surg Soc. 2011;80(6):390-6.

22. Olper L, Cabrini L, Landoni G, Rossodivita A, Nobile L, Monti G, et al. Non-invasive ventilation after cardiac surgery outside the Intensive Care Unit. Minerva Anestesiol. 2011;77(1):40-5.

23. Bellinetti LM, Thomson JC. Avaliação muscular respiratória nas toracotomias e laparotomias superiores eletivas. J Bras Pneumol. 2006;32(2):99-105.

24. Bastos TAB, Melo VA, Silveira FS, Guerra DR. Influência da força muscular respiratória na evolução de pacientes com insuficiência cardíaca após cirurgia cardíaca. Rev Bras Cir Cardiovasc. 2011;26(3):355-63.

25. Freynet A, Falcoz PE. Does non-invasive ventilation associated with chest physiotherapy improve outcome after lung resection? Interac Cardiovasc Thorac Surg. 2008;7(6):1152-4.

26. Zarbock A, Mueller E, Netzer S, Gabriel A, Feindt P, KindgenMilles D. Prophylactic nasal continuous positive airway pressure following cardiac surgery protects from postoperative pulmonary complications: a prospective, randomized, controlled trial in 500 patients. Chest. 2009;135(5):1252-9.

27. Refai M, Pompili C, Salati M, Xiumè F, Sabbatini A, Brunelli A. Can maximal inspiratory and expiratory pressures during exercise predict complications in patients submitted to major lung resections? A prospective cohort study. Eur J Cardiothorac Surg. 2013;1-6.

28. Riedi C, Mora CTR, Driessen T, Coutinho MCG, Mayer DM, Moro $\mathrm{FL}$, et al. Relação do comportamento da força muscular com as complicações respiratórias na cirurgia cardíaca. Rev Bras Cir Cardiovasc. 2010;25(4):500-5.

29. Savci S, Degirmenci B, Saglam M, Arikan H, Inal-Ince D, Turan HN, et al. Short-term effects of inspiratory muscle training in coronary artery bypass graft surgery: a randomized controlled trial. Scand Cardiovasc J. 2011;45(5):286-93. 